J. Amer. Soc. Hort. Sci. 124(6):666-670. 1999.

\title{
Genetic Variation and Population Structure of Castanea pumila var. ozarkensis
}

\author{
Fenny Dane and Leigh K. Hawkins \\ Department of Horticulture, Auburn University, AL 36849 \\ Hongwen Huang \\ Wuhan Institute of Botany, Chinese Academy of Sciences, Wuhan, Hubei 430074, People's Republic of China
}

ADDITIONAL INDEX wORDS. Ozark chinkapin, conservation, genetic diversity, isozymes, randomly amplified polymorphic DNA, RAPD

\begin{abstract}
Genetic variation among nine populations of Ozark chinkapin [Castanea pumila (L.) Mill. var. ozarkensis (Ashe) Tucker], threatened by their susceptibility to chestnut blight (Cryphonectria parasitica (Murrill) Barr), was investigated. Population genetic parameters estimated from isozyme variation suggest the populations have a higher genetic diversity $\left(H_{e}\right.$ $=0.227$ ) than populations of the other Castanea Mill. species on the North American continent, the American chestnut $(C$. dentata (Marsh.) Borkh.) High levels of heterozygosity were detected within the populations, but nonsignificant differences in genetic diversity were observed among the different populations. Principal component analysis based on isozyme allele frequencies or randomly amplified polymorphic DNA phenotype frequencies showed clustering of the same populations. Populations with high levels of genetic diversity and unusual alleles should be the focal point of conservation biologists for capturing much of the genetic variation of the species.
\end{abstract}

The genus Castanea contains several species, some of which like the American chestnut $(C$. dentata) and chinkapin $(C$. pumila) are susceptible to chestnut blight, caused by the fungus Cryphonectria parasitica. The fungus was introduced into North America at the beginning of this century on nursery stock of resistant Japanese chestnut (C. crenata Sieb.) species (Anagnostakis, 1992). Chestnut blight reduced the American chestnut from one of the most important timber and nut producing tree species in the deciduous forests of the eastern United States to an understory shrub. Considerable efforts have been made to transfer blight resistance from the Chinese chestnut ( $C$. mollissima B1.) into the American chestnut in an attempt to combine the blight resistance of the Chinese species with the desirable timber qualities of the American chestnut (Burnham, 1988; Hebard, 1996).

Although the plight of the American chestnut is well known, the lesser known member of the genus, the chinkapin, has been neglected by taxonomists and field biologists and has even been considered as an example of one of the most mistreated and misrepresented native North American nut trees (Payne et al., 1994). The chinkapin is endemic to the eastern and southeastern United States from Pennsylvania to Florida, eastern Texas, southwestern Missouri, and west-central Kentucky. It includes shrubs and trees that occupy dry, open, usually disturbed sites from near sea level to $\approx 1400 \mathrm{~m}$ in altitude. The species exists as two regional varieties (Johnson, 1988). Castanea pumila variety pumila, the Allegheny chinkapin, is widespread and a highly variable shrub or tree, while $C$. pumila var. ozarkensis, the Ozark chinkapin, is restricted to the Ozark plateau in Arkansas, where it persists mainly as trees or stump sprouts of various sizes (Johnson, 1988; Logan and

Received for publication 20 Nov. 1998. Accepted for publication 15 Aug. 1999. This research was supported in part by the Arkansas National Heritage Commission, Little Rock. The authors are grateful to John Logan, Arkansas National Heritage Commission; Karen Tinkle, Biologist, Sylamore Ranger District; Jan Self, Jeff Briggler, and Ralph Odegard, Biologists, Ozark National Forest, Ark.; George Johnson, Arkansas Tech. Univ., Russellville; and Jerry L. Michael, Andrews Forestry Science Lab., U.S. Dept. Agr. For. Serv., Auburn, Ala., for assistance with collection of chinkapin samples. The cost of publishing this paper was defrayed in part by the payment of page charges. Under postal regulations, this paper therefore must be hereby marked advertisement solely to indicate this fact.
Dane, personal observation). The two varieties differ in reproductive and vegetative characters, as well as in leaf micromorphology and flavonoid constituents (Johnson, 1988).

Chestnut blight has extirpated the Ozark chinkapins from Alabama and severely affected the variety in the Ozarks (F. Dane, personal observation; Johnson, 1988). Castanea pumila var. ozarkensis is threatened and a conservation plan is needed (J.Logan, Arkansas National Heritage Commission). The Allegheny chinkapin is reported to be somewhat resistant to chestnut blight (Payne et al., 1994), although diseased and heavily cankered trees have been found in Georgia and Louisiana (Wallace and Peacher, 1970), Alabama and Florida (J.D. Norton and F. Dane, personal observation).

Conservation organizations must frequently choose populations of plants to acquire and protect. Although many factors enter into such decisions, conservation of genetically diverse populations should be a priority (Godt and Hamrick, 1998). Any effort to conserve Castanea germplasm would have increased chances of success if as much as possible is known about the genetic diversity of the species. Populations that lack genetic diversity or variation for specific traits (such as disease resistance) often lack the ability to adapt to new and changing environmental conditions and are more prone to extinction. The uniform susceptibility of the American chestnut to blight has occasionally been cited as an example of a species without much genetic variability (Huang et al., 1998). An understanding of adaptive genetic differentiation among populations is of primary importance, but difficult to obtain. In contrast, allozymes, because of their codominant nature, neutrality relative to natural selection, and low sampling cost, have been used extensively in studies of the genetic diversity, geographical variation, and gene structure in natural forest tree populations (Hamrick et al., 1992; Huang et al., 1994b, 1998).

Allozyme markers have been used to evaluate genetic diversity in several Castanea species. These studies indicated that the overall genetic variability of the American chestnut is significantly lower than that observed in the Chinese and European Castanea species. Values for percentage polymorphic loci $(\mathrm{P})$ of 85.4 , mean number of alleles per locus (A) of 2.1, and expected heterozygosity $\left(\mathrm{H}_{\mathrm{e}}\right)$ of 0.305 were reported for the Chinese chestnut, while $\mathrm{P}=59.7, \mathrm{~A}=$ 
1.7, and $\mathrm{H}_{\mathrm{e}}=0.151$ for the American chestnut (Huang et al., $1994 \mathrm{~b}, 1998$ ), and values of $\mathrm{P}=76.9, \mathrm{~A}=1.5$, and $\mathrm{H}_{\mathrm{e}}=0.32$ were reported for the European chestnut (C. sativa Mill.) (Villani et al., 1991). Presently, little information is available on the genetic diversity of geographic populations of the chinkapins. Our objectives were two fold: (1) to characterize the diversity within and between populations of the Ozark chinkapin to gain an understanding of overall genetic composition and its relationship to the vulnerability of $C$. pumila var. ozarkensis to chestnut blight, and (2) to apply this information to conservation strategies of remnant C. pumila var. ozarkensis populations.

\section{Materials and Methods}

Plant Materials. In Fall 1996 and 1997, nuts from nine populations of $C$. pumila var. ozarkensis were sampled from across the native range of the species in the Ozark National Forests of Arkansas. Seven populations $\left(S_{1}\right.$ to $\left.S_{7}\right)$ were collected in the Sylamore Ranger District (Fig. 1) and two populations (J and N) in the Buffalo Ranger District. Population J was collected at the Fairview site along Highway 7, $55 \mathrm{~km}$ north of Russellville, Arkansas, while population N was collected at NE NW, Sec 4, T13N, R21W, in Newton County (Deer Quad), Arkansas.

Allozyme analysis. Enzymes were extracted from half a nut using a $2 \%$ glycine buffer ( $\mathrm{pH}$ 8.6). The isoelectric focusing polyacrylamide slab gel system of $\mathrm{pH} 4$ to 9 described earlier (Huang et al., 1994a) or precast agarose gels (Hypure $\mathrm{pH} 4$ to 6 or $\mathrm{pH} 3$ to 7) were used in this study because of their high resolution. Gels were assayed for acid phosphatase [ACP; EC (Enzyme Commission) 3.1.3.2], alcohol dehydrogenase (ADH; EC 1.1.1.1), esterase (EST; EC 3.1.1.-), diaphorase (DIA: EC 1.8.1.4.), isocitrate dehydrogenase(IDH;EC 1.1.1.41), malic enzyme(ME;EC 1.1.1.40),

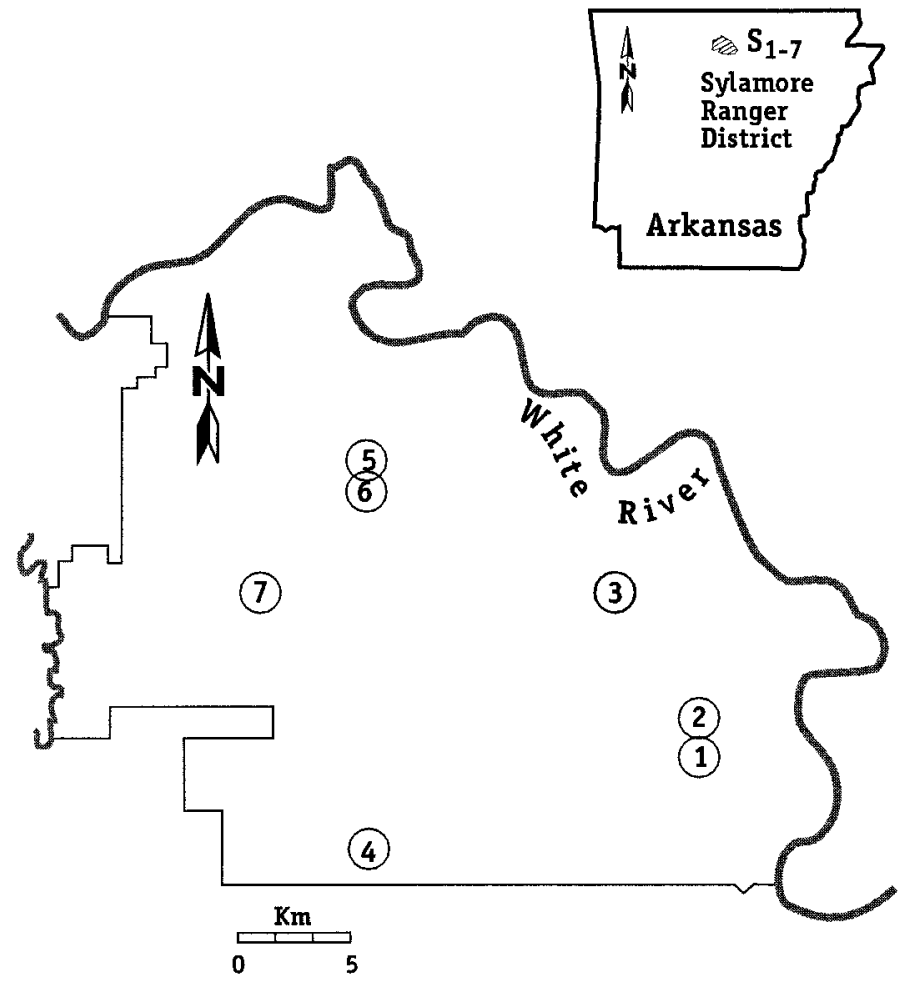

Fig. 1. Range map with collection sites of seven Ozark chinkapin populations in Arkansas. peroxidase (PRX; EC 1.11.1.7), phosphoglucoisomerase (PGI; EC 5.3.1.3), shikimate dehydrogenase (SKD; EC 1.1.1.25), superoxide dismutase (SOD; EC 1.12.1.1), and triosephosphate isomerase (TPI; EC 5.3.1.1). Gels were stained as described by Wendel and Weeden (1989). The following 14 loci were scored on chinkapin populations when possible: Acp-1,Acp-2,Adh-1,Dia-1, Dia-6, Est2, Est-4, Idh, Pgi-2, Prx-1, Skd-1, Skd-2, Sod-1, and Tpi. Genetic analysis and allele designation of those loci have been described (Huang et al., 1994a).

RAPD ANALYSIS. Genomic DNA was extracted from half a nut using a CTAB-based procedure (Weising et al., 1995) or nucleon plantDNA isolation kit(AmershamPharmaciaBiotech, Piscataway, N.J.) and quantified using a fluorometer. Polymerase chain reactions (PCR) were carried out in a $25 \mu \mathrm{L}$ volume containing 10 $\mathrm{mmol} \cdot \mathrm{L}^{-1}$ Tris- $\mathrm{HCl} ; 1.5 \mathrm{mmol} \cdot \mathrm{L}^{-1} \mathrm{MgCl}_{2} ; 50 \mathrm{mmol} \cdot \mathrm{L}^{-1} \mathrm{KCl}(\mathrm{pH}$ 8.3 ), $0.2 \mathrm{mmol} \cdot \mathrm{L}^{-1}$ of each $\mathrm{dNTP}, 5 \mathrm{pmol} \cdot \mathrm{L}^{-1}$ decamer oligonucleotide primer, $10 \mathrm{ng}$ genomic DNA, and 1 unit Taq DNA polymerase (PE). DNA amplifications were performed in a Perkin Elmer 2400 DNA thermal cycler (Perkin Elmer, Foster City, Calif.) programmed as follows: 10 min at $94^{\circ} \mathrm{C} ; 35$ cycles of $45 \mathrm{~s}$ at $94^{\circ} \mathrm{C}, 45 \mathrm{~s}$ at $36^{\circ} \mathrm{C}, 2 \mathrm{~min}$ at $72{ }^{\circ} \mathrm{C}$, followed by $5 \mathrm{~min}$ at $72{ }^{\circ} \mathrm{C}$. Amplification products were analyzed by electrophoresis on $1.2 \%$ agarose gels, detected by staining with ethidium bromide. The gels were photographed under ultra violet light with Polaroid 667 film (Eastman Kodak Co). A 100-bp DNA ladder (GibcoBRL, Rockville, Md.) was used as a molecular size marker. Eighteen randomly amplified polymorphic DNA (RAPD) loci chosen from the chestnut recombinational linkage map (Kubisiak et al., 1997) were scored: A18 $8_{0650}, \mathrm{~A} 18_{0850 \text {, }}$ $\mathrm{G} 17_{0525}, \mathrm{G} 17_{1300}, \mathrm{G} 17_{1350}, \mathrm{G} 17_{1500}, 153_{0700}, 153_{0900}, 153_{1200}, 153_{1900}$, $531_{0800}, 531_{1100}, 557_{0650}, 557_{0850}, 557_{0900}, 557_{1000}, 551_{0900}$, and $551_{1650}$.

Data anAlysis. Allele frequencies for isozyme loci were estimated (Nei,1978). A set of measures of intra- and interpopulation genetic statistics were generated using a statistical program developed by M.D. Loveless and A. Schnabel, and BIOSYS-1 (Swofford and Selander, 1981) including: $\mathrm{P}, A$, effective number of alleles per locus $\left(A_{\mathrm{e}}\right)$, observed heterozygosity $\left(H_{\mathrm{o}}\right), H_{\mathrm{e}}$, total genetic diversity $\left(H_{\mathrm{T}}\right)$, genetic diversity within population $\left(H_{\mathrm{s}}\right)$, genetic diversity between populations $\left(D_{\mathrm{ST}}\right)$, relative magnitude of genetic differentiation among populations $\left(G_{\mathrm{ST}}=D_{\mathrm{ST}} / H_{\mathrm{T}}\right)$ (Nei, 1978), and $\chi^{2}$ tests for heterogeneity of allele frequencies among populations. $F$ statistics were calculated including the fixation index of individuals within populations $\left(F_{\text {IS }}\right)$, fixation index with respect to the total population $\left(F_{\mathrm{IT}}\right)$, and proportion of genetic differentiation $\left(F_{\mathrm{ST}}\right)$ (Wright, 1978). Outcrossing rates, t, were estimated using the equation $\mathrm{F}_{\mathrm{e}}=(1-\mathrm{t}) /(1+\mathrm{t})$, for which $\mathrm{F}_{\mathrm{e}}$ was estimated by $\left[\left(\mathrm{H}_{\mathrm{e}}-\mathrm{H}_{\mathrm{o}}\right) / \mathrm{H}_{\mathrm{e}}\right]$ (Berg and Hamrick, 1992). Nei's genetic distance and identity (Nei, 1978 ), as well as Rogers modified genetic distance (Wright, 1978) were calculated for all pairwise combinations of populations. A dendrogram was constructed based on the matrix of Rogers' distance using unweighted pair-group method using arithmetic average (UPGMA). The principal components analysis (PCA) was performed based on isozyme allele frequency data of populations and RAPD phenotype (presence versus absence of bands) frequencies using PCSAS for Windows (SAS Inst., Inc., 1989).

\section{Results}

Relatively high levels of genetic diversity were found for $C$. pumila var. ozarkensis based on detection of 21 alleles at 10 isozyme loci across nine populations with values of $\mathrm{P}=80, \mathrm{~A}=$ 2.10 , and $\mathrm{H}_{\mathrm{e}}=0.272$ (Table 1 ). A mean number of $63.3 \%$ of the 
loci were variable at the population level with $\mathrm{A}=2.12$ and $\mathrm{H}_{\mathrm{e}}=$ 0.227 . Significant deviations from Hardy Weinberg expectations were observed for Pgi-2 in almost all populations, for Est-4 and Acp-2 in four populations, for $S k d-1$ and Dia-6 in three populations, for $S k d-2$ in two populations, and Sod-1 in one population. Most of the deviations from Hardy-Weinberg equilibrium were observed in populations $\mathrm{S}_{1}$ and $\mathrm{S}_{4}$. These populations contained several large trees with burs and nuts in clear-cut areas, while nut production in some of the other populations was quite sparse and sampling was limited. However, genetic diversity values detected in populations with low sampling size $\left(\mathrm{J}\right.$ and $\left.\mathrm{S}_{5}\right)$ were not significantly different from those detected in populations with larger sampling size (Table 1). High levels of heterozygotes or heterozygote advantage were detected as indicated by high negative mean fixation index $\left(\mathrm{F}_{\mathrm{IS}}\right)$ of -0.314 (Table 2).

Significant differences in allele frequencies among populations were found for all polymorphic loci except for Pgi-2 (Table $2)$. A relatively high proportion of the total gene diversity resided within the populations $\left(>85 \% ; \mathrm{G}_{\mathrm{ST}}=0.147\right)$. Nei's (1972) genetic identity and distance values were estimated for all pairwise comparisons among populations and ranged from 0.873 for $S_{1}$ and $S_{5}$ to 0.994 for $S_{1}$ and $S_{3}$. These relationships are illustrated by the UPGMA phenogram (Fig. 2) which clusters genetically similar populations. The geographically isolated populations ( $\mathrm{J}$ and $\mathrm{N}$ ) were closely related genetically to the populations of the Sylamore District some of which were spatially in closer proximity to each other.

Genetic relationships among five different populations $\left(\mathrm{S}_{5}, \mathrm{~S}_{6}\right.$, $\mathrm{S}_{7}, \mathrm{~J}$, and $\mathrm{N}$ ), collected in 1997, were examined further using four additional isozyme loci and RAPD phenotype frequencies. An increase in the number of isozyme loci (from 10 to 14) did not affect mean genetic diversity at the population level $\left(\mathrm{H}_{\mathrm{e}}\right.$ decreased from 0.219 to 0.210 ), but resulted in a lowering of the mean $\mathrm{G}_{\mathrm{ST}}$ value from 0.147 to 0.122 , and a redistribution of the variation from among to within the different populations. Because of the low number of chinkapin nuts available per tree per population, RAPD marker data could only be obtained on eight individuals per population $S_{5}, S_{6}$, and $S_{7}$, and five individuals per population $\mathbf{J}$ and $\mathrm{N}$, respectively. Relationships suggested by principal component analysis (PCA) of RAPD data using 18 loci

Table 1. Genetic diversity statistics for nine $C$. pumila var. ozarkensis populations collected in Arkansas based on variability at 10 isozyme loci.

\begin{tabular}{|c|c|c|c|c|c|c|c|}
\hline Population & $\begin{array}{l}\text { Trees } \\
\text { (no.) }\end{array}$ & $\begin{array}{c}\text { Nuts } \\
\text { sampled } \\
\text { (no.) }\end{array}$ & $\mathrm{P}^{\mathrm{z}}$ & $\mathrm{A}^{\mathrm{y}}$ & $\mathrm{H}_{\mathrm{o}}(\mathrm{SD})^{\mathrm{x}}$ & $\mathrm{H}_{\mathrm{e}}(\mathrm{SD})^{\mathrm{w}}$ & $\mathrm{t}^{\mathrm{v}}$ \\
\hline $\mathrm{S}_{1}$ & 11 & 29 & 70 & 1.8 & $0.366(0.063)$ & $0.265(0.074)$ & 2.23 \\
\hline $\mathrm{S}_{2}$ & 10 & 46 & 60 & 1.6 & $0.315(0.049)$ & $0.228(0.071)$ & 2.23 \\
\hline $\mathrm{S}_{3}$ & 6 & 15 & 50 & 1.5 & $0.313(0.081)$ & $0.225(0.078)$ & 2.28 \\
\hline $\mathrm{S}_{4}^{3}$ & 11 & 38 & 70 & 1.7 & $0.411(0.048)$ & $0.254(0.072)$ & 4.37 \\
\hline $\mathrm{S}_{5}^{4}$ & 1 & 36 & 70 & 1.7 & $0.267(0.053)$ & $0.208(0.064)$ & 1.70 \\
\hline $\mathrm{S}_{6}$ & 4 & 34 & 70 & 1.9 & $0.266(0.048)$ & $0.191(0.069)$ & 2.30 \\
\hline $\mathrm{S}_{7}$ & 5 & 7 & 60 & 1.6 & $0.314(0.090)$ & $0.192(0.071)$ & 4.48 \\
\hline $\mathrm{J}$ & 1 & 8 & 50 & 1.6 & $0.438(0.080)$ & $0.249(0.083)$ & 7.33 \\
\hline $\mathrm{N}$ & 3 & 27 & 70 & 1.9 & $0.293(0.054)$ & $0.257(0.080)$ & 1.33 \\
\hline Population mean & 5.8 & 26.7 & 63 & 1.7 & $0.331(0.022)$ & $0.227(0.024)$ & 2.69 \\
\hline Variety mean & 5.8 & 26.7 & 80 & 2.1 & 0.341 & 0.272 & \\
\hline
\end{tabular}

ㄹercentage of polymorphic loci.

${ }^{y}$ Mean number of alleles per locus.

${ }^{\mathrm{x}}$ Observed heterozygosity \pm SD.

${ }^{\mathrm{w}}$ Hardy-Weinberg expected heterozygosity \pm SD.

${ }^{\mathrm{v}}$ Outcrossing rate.

Table 2. Genetic variability statistics and Wrights $F$ statistics for eight polymorphic isozyme loci in nine Ozark chinkapin populations in Arkansas. ${ }^{\mathrm{Z}}$

\begin{tabular}{|c|c|c|c|c|c|c|}
\hline Locus & $\mathrm{H}_{\mathrm{T}}^{\mathrm{y}}$ & $\mathrm{H}_{\mathrm{S}}{ }^{\mathrm{x}}$ & $\mathrm{G}_{\mathrm{ST}}{ }^{\mathrm{w}}$ & $\mathrm{F}_{\mathrm{IS}}^{\mathrm{v}}$ & $\mathrm{F}_{\mathrm{IT}}^{\mathrm{u}}$ & $\chi^{2}(\mathrm{df})^{t}$ \\
\hline$\overline{A d h-1}$ & 0.124 & 0.119 & 0.037 & -0.113 & -0.071 & $18.03(8)^{*}$ \\
\hline Acp-2 & 0.142 & 0.344 & 0.145 & -0.411 & -0.207 & $89.97(16)^{* *}$ \\
\hline Dia-6 & 0.410 & 0.215 & 0.478 & -0.412 & -0.262 & $230.15(8)^{* *}$ \\
\hline Est-4 & 0.484 & 0.408 & 0.157 & -0.606 & -0.353 & $155.41(16)^{* * *}$ \\
\hline Pgi-2 & 0.402 & 0.344 & 0.015 & -0.713 & -0.705 & $14.71(16)^{\mathrm{NS}}$ \\
\hline$S k d-1$ & 0.467 & 0.402 & 0.139 & -0.269 & -0.093 & $66.90(8)^{* * *}$ \\
\hline$S k d-2$ & 0.280 & 0.250 & 0.106 & 0.021 & 0.125 & $51.03(8)^{* *}$ \\
\hline Sod-1 & 0.060 & 0.055 & 0.096 & 0.010 & 0.106 & $46.47(8)^{* *}$ \\
\hline Mean (poly) & 0.341 & 0.285 & 0.147 & -0.314 & -0.117 & \\
\hline
\end{tabular}

zTwo loci, Tpi and Idh, were monomorphic.

yTotal genetic diversity.

${ }^{\mathrm{x}}$ Genetic diversity within populations.

wProportion of total genetic diversity found among populations.

vFixation index within populations.

uFixation index with respect to total population.

${ }^{\mathrm{t}}$ Test for heterogeneity with degrees of freedom in parentheses

Ns, ${ }^{*},{ }^{* *}$ Nonsignificant or significant at $P=0.05$ or 0.01 , respectively. 

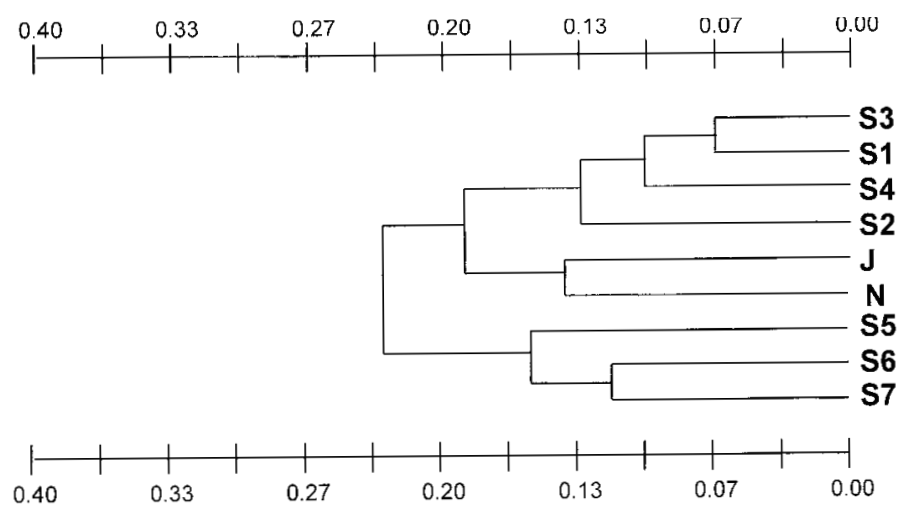

\section{Rogers Distance}

Fig. 2. UPGMA dendrogram of allozyme markers based on modified Rogers'genetic distance (Wright, 1978) between C. pumila var. ozarkensis populations.

indicated that the first component, which accounted for $39 \%$ of the RAPD band variation, separated $\mathrm{S}_{6}, \mathrm{~S}_{7}$, and J populations from $\mathrm{S}_{5}$ and $\mathrm{N}$ (Fig. 3A and $\mathrm{B}$ ), the second component, which accounted for $30 \%$ of the variation separated $\mathrm{S}_{7}$ and $\mathrm{J}$ from $\mathrm{S}_{6}$. Using isozyme data, the first principal component, which accounted for $35 \%$ of the variation, separated $\mathrm{N}$ from $\mathrm{S}_{5}$ and clustered the other populations (Fig 3C and D).

\section{Discussion}

GENETIC DIVERSITY IN C. pumila VAR. ozarkensis. The American Castanea species have not recovered from the devastating effects of fungal colonization by Cryphonectria parasitica, even though many efforts have been made to combat the disease. Population genetic studies conducted on surviving American chestnut populations indicated that the species has a lower level of genetic diversity $\left(\mathrm{H}_{\mathrm{e}}=0.151\right)$ than Chinese $\left(\mathrm{H}_{\mathrm{e}}=\right.$ $0.328)$ and European $\left(\mathrm{H}_{\mathrm{e}}=0.317\right)$ Castanea species (Huang et al., 1994b, 1998; Villani et al., 1991). The mean genetic diversity of the surviving Ozark chinkapin populations $\left(\mathrm{H}_{\mathrm{e}}=0.227\right)$ was found to be greater than that of the relict American chestnut, even though its range at the present time is limited to the Ozark mountains. Plant species with small geographic ranges maintain considerably less genetic variation than widespread species (Hamrick and Godt, 1996), although exceptions to this generalization have been reported (Godt and Hamrick, 1996). It must be reiterated that the Ozark chinkapin samples were analyzed at the cotyledon stage, while mature buds from sprouts of large stumps of regenerated trees, remnants of the original blight-killed trees, were used for analyses of American chestnut populations (Huang et al., 1998). Parks et al. (1994) found significant differences between fixation indices of seedling and adult generations of tulip poplar (Liriodendron tulipifera L.). Adult generations showed a reduction in homozygosity due to culling of selfed or

highly inbred seedlings, which would result in higher genetic diversity values for adult as compared to seedling populations.

While the narrow genetic diversity of the American chestnut might have contributed to its demise (Huang et al., 1998), the higher level of genetic diversity detected in the Ozark chinkapin might be related to its origin. The Ozark chinkapin is thought to be the ancestral type and less evolved than the Allegheny chinkapin, C. pumila var. pumila, because of its lack of stoloniferous growth, its arborescent habit, adaptation to older stages of succession and to areas of higher soil fertility (Johnson, 1988). The capability of C. pumila var. pumila for stoloniferous growth is considered to be an adaptation for survival in early successional stages and areas of low soil fertility. Castanea pumila var. pumila is common in frequently disturbed, open sites (Johnson, 1988). Castanea pumila var. pumila and $C$. dentata, the American chestnut, are sympatric over a large portion of their ranges but show few signs of possible introgression and relatively rare occurrence of $F_{1}$ hybrids even though their flowering phenology is the same (Johnson, 1988). Fossil records offer no indications as to the time or place of origin of C. pumila, although Johnson (1988) considers C. pumila derived from $C$. dentata by reduction in the number of cupule valves and flowers. More detailed population studies of the Allegheny chinkapin are in progress, and should elucidate the evolutionary relationships between and within these American Castanea species and might provide a clearer understanding of the relationship between the genetic diversity of the species and their vulnerability to chestnut blight.

DisTRIBUTION AND GEOGRAPHIC PATTERNS OF GENETIC DIVERSITY. The proportion of genetic diversity found among the nine $C$. pumila var. ozarkensis populations $\left(\mathrm{G}_{\mathrm{ST}}=0.147\right)$ was somewhat higher than that observed for other species in the genus $(C$. sativa $\mathrm{F}_{\mathrm{ST}}=0.10$, . dentata $\mathrm{G}_{\mathrm{ST}}=0.11$; Villani et al., 1991; Huang et al.,

Fig. 3. Principal components analysis of (A and B) RAPD genotype frequencies and $(\mathbf{C}$ and $\mathbf{D})$ allozyme allele frequencies of five $C$. pumila var. ozarkensis populations.

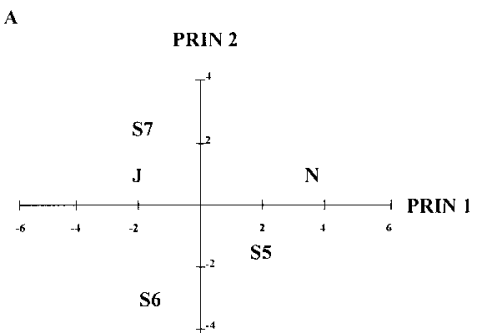

C

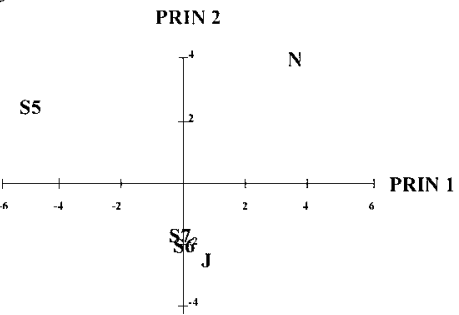

B

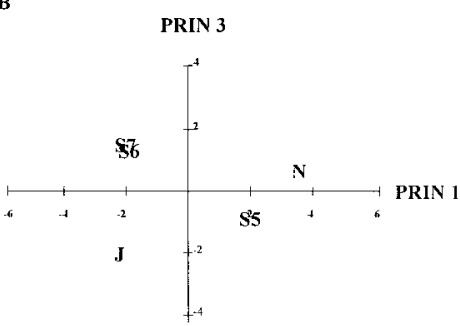

D

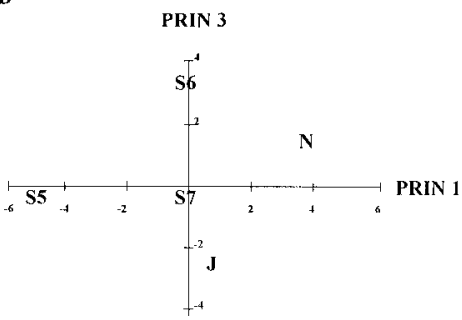


1998), and other long lived perennial species $\left(\mathrm{G}_{\mathrm{ST}}=0.076\right)$, windoutcrossing species (0.099) or late successional species $(0.101)$ (Hamrick and Godt, 1996). Differences in $\mathrm{G}_{\mathrm{ST}}$ were observed from locus to locus with values ranging from 0.015 for Pgi-2 to 0.478 for Dia-6. Chinkapin nuts collected from geographically isolated Ozark chinkapin populations were genetically similar and spatial patterning of isozyme allele frequencies was not detected (data not shown). Similar results were obtained for the American chestnut populations. A north-south cline was observed in allele frequencies of only one locus $S k d-2$, specific to American Castanea species (Huang et al., 1998). Although unusual alleles were observed in a few populations (Sod-1b was only associated with Sylamore population $\mathrm{S}_{1}$ and $\mathrm{S}_{4}$, while Dia$1 c$ and Dia-6c were detected in population $\mathrm{N}$ ), these results should be interpreted cautiously because of limited sampling sizes.

CONSERVATION CONSIDERATIONS FOR RESTORATION OF C. pumila VAR. ozarkensis. Population management will become necessary for conservation of many native North-American plant species as more species face extinction. Formulating an appropriate conservation strategy will require knowledge of the life history characteristics and how a species is affected by biotic and abiotic interactions within the community, as well as understanding specific threats to the species. An understanding of the genetic diversity present in a species and the distribution of this variation among populations will also be critical for formulation of appropriate management strategies (Godt and Hamrick, 1998). Levels of variability within and among plant populations are known to be influenced by breeding systems. Woody angiosperms with open recombination systems, either animal or wind-pollinated, typically have most of their allozyme variation partitioned within populations (Hamrick and Godt, 1996). Populations of low genetic variability have a reduced potential to adapt to environmental change (Ellstrand and Elam, 1993).

The genetic variation of the Ozark chinkapin was found to be relatively high with most of the heterozygosity harbored within populations. The mean $\mathrm{F}_{\mathrm{IS}}$ value for the Ozark chinkapin indicated high levels of outcrossing and gene flow among populations. Indirect estimates of outcrossing rates $($ mean $t=2.70)$ suggested that most populations are highly outcrossed. Johnson (1988) found the Castanea species to be mainly wind-pollinated and detected infrequent occurrences of self-compatibility and apomixis.

Chestnut blight has had a major effect on Ozark chinkapins, killing individual stems quickly especially in dense populations and reducing population size as was evidenced in population $J(G$. P. Johnson and F. Dane, personal observation). However, stem regeneration occurs from the root collar, and ex situ efforts can and need to be undertaken to preserve and multiply these populations. Paillet (1993) reported that locally $>75 \%$ of root systems of pre-blight chinkapins in Arkansas were alive after blight was first introduced. However, while most of these populations are on public lands, some are on private property (population N, for example) and conservation efforts should focus on these populations and consider the establishment of tree reservations. Propagation of plants from nuts is preferred, since it would include the widest range of genetic diversity. Ecological management and habitat conservation will be necessary to conserve populations in situ. Full restoration of the Ozark chinkapin may prove complicated and might require establishment of an aggressive backcross breeding program designed to transfer the blight resistance of the Chinese chinkapin ( $C$. henryi), but would be important to conserve and reestablish this underused native nut tree (Payne et al., 1994).

\section{Literature Cited}

Anagnostakis, S.L. 1992. Chestnuts and the introduction of chestnut blight. Annu. Rpt. Northern Nut Growers' Assn. 83:23-37.

Berg, E.E. and J.L. Hamrick. 1992. Quantification of genetic diversity at allozyme loci. Can. J. For. Res. 27:415-424.

Burnham, C.R. 1988. The restoration of the American chestnut. Amer. Scientist 76:478-487.

Ellstrand, N.C. and D.R. Elam 1993. Population genetic consequences of small population size: Implications for plant conservation. Annu. Rev. Ecol. Systematics 24:217-242.

Godt, M.J.W. and J.L. Hamrick. 1996. Genetic diversity and morphological differentiation in Liatris helleri (Asteraceae), a threatened plant species. Biodiversity Conservation 5:461-471.

Godt, M.J.W. and J.L. Hamrick. 1998. Allozyme diversity in the endangered pitcher plant Sarracenia rubra sp. alabamensis (Sarraceniaceae) and its close relative S. rubra sp. rubra. Amer. J. Bot. 85:802-810.

Hamrick, J.L. and M.J.W. Godt. 1996. Conservation genetics of endemic plant species, p. 281-304. In: J.L. Avise and J.L. Hamrick (eds.). Conservation genetics: Case histories from nature. Chapman and Hall, N.Y.

Hamrick, J.L., M.J.W. Godt, and S.L. Sherman-Broyles. 1992. Factors influencing levels of genetic diversity in woody plant species. New Forests 6:95-124.

Hebard, F. V. 1996. Notes from Meadowview. J. Amer. Chestnut Found. 10:8-12.

Huang, H., F. Dane, and T.L. Kubisiak. 1998. Allozyme and RAPD analysis of the genetic diversity and geographic variation in wild populations of the American chestnut Castanea dentata (Fagaceae). Amer. J. Bot. 85:10131021.

Huang, H., F. Dane, and J.D. Norton. 1994a. Genetic analysis of 11 polymorphic isozyme loci in chestnut species and characterization of chestnut cultivars by multi-locus allozyme genotypes. J. Amer. Soc. Hort. Sci. 119:840-849.

Huang, H., F. Dane, and J.D. Norton. 1994b. Allozyme diversity in Chinese, Seguin and American chestnut (Castanea sp.). Theor. Appl. Genet. 88:981985.

Johnson, G.P. 1988. Revision of Castenea sect. Balanocastanon (Fagaceae). J. Arnold Arboretum 69:25-49.

Kubisiak, T.L., F.V. Hebard, C.D. Nelson, J. Zhang, R. Bernatzky, H. Huang, S.L. Anagnostakis, and R. L. Doudrick. 1997. Mapping resistance to blight in an interspecific cross in the genus Castanea using morphological, isozyme, RFLP and RAPD markers. Phytopathology 87:751-759.

Nei, M. 1972. Genetic distance between populations. Amer. Naturalist 106:283292.

Nei, M. 1978. Estimation of average heterozygosity and genetic distance from a small number of individuals. Genetics 89:583-590.

Paillet, F.L. 1993. Growth form and life histories of American chestnut and Allegheny and Ozark chinquapin at various North American sites. Bul. Torrey Bot. Club 120:257-268.

Parks, C.R., J.F. Wendel, M.M. Sewell, and Y.-L. Qiu. 1994. The significance of allozyme variation and introgression in the Liriodendron tulipifera complex (Magnoliaceae). Amer. J. Bot. 81:878-889.

Payne, J.A., G. Miller, G.P. Johnson, and S.D. Senter. 1994. Castanea pumila (L.) Mill.: An underused native nut tree. HortScience 29:62, 130-131.

SAS Institute, Inc. 1989. SAS/stat user's guide. Release 6.03. SAS, Raleigh, N.C.

Swofford. D.L. and R.B. Selander 1981. BIOSYS-1: A FORTRAN program for comprehensive analysis of electrophoretic data in population genetics and systematics. J. Hered. 72:281-283

Villani, F., M. Pigliucci, S. Benedettelli, and M. Cherubini. 1991. Genetic differentiation among Turkish chestnut (Castanea sativa Mill. ) populations. Heredity 66:131-136.

Wallace, H.N. and P.H. Peacher. 1970. Chinkapin in Louisiana infected with Endothia parasitica. Plant Dis. Rpt. 54:713.

Weising, K., H. Nybom, K. Wolff, and W. Meyer. 1995. DNA fingerprinting in plants and fungi. CRC Press, Boca Raton, Fla.

Wendel, J.F. and N.F. Weeden. 1989. Visualization and interpretation of plant isozymes, p. 9-33. In: D.E. Soltis and P.S. Soltis (eds.). Isozymes in plant biology. Dioscorides Press, Portland, Ore.

Wright, S. 1978. Evolution and the genetics of populations. Vol 4: Variability within and among populations. Univ. Chicago Press, Chicago, Ill. 